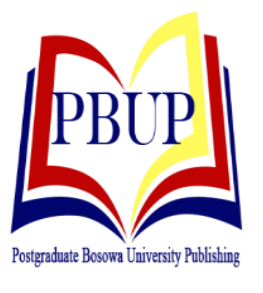

Postgraduate Bosowa University Publishing (PBUP)

Indonesian Journal of Business and Management e-ISSN: 2460-3767 p-ISSN: 2656-6885

https://postgraduate.universitasbosowa.ac.id/index.php/jbm

\title{
PENGARUH NON PERFORMING LOAN, LOAN DEPOSIT TO RATIO, BEBAN OPERASIONAL PENDAPATAN OPERASIONAL DAN BANK SIZE TERHADAP PROFITABILITAS MELALUI CAPITAL ADEQUACY RATIO
}

\author{
The Effect of Non-Performing Loan, Loan Deposit to Ratio, Operational Expenses of Operational \\ Income and Bank Size on the Profitability Through Capital Adequacy Ratio
}

\author{
Dahlan $^{1}$, Osman Lewangka ${ }^{2}$, Firman Menne ${ }^{2}$ \\ ${ }^{1}$ Mahasiswa Magister Manajemen Universitas Universitas Bosowa \\ ${ }^{2}$ Program Studi Manajemen Program Pascasarjana Universitas Bosowa
}

Email: dahlanmks9@gmail.com

Diterima: 3 April 2020/Disetujui: 05 Juni 2020

\begin{abstract}
ABSTRAK
Tujuan dari penelitian ini adalah untuk mengetahui pengaruh langsung dan tidak langsung Non Performing Loan, Loan to Deposit Ratio, Beban Operasional Pendapatan Operasional dan Bank Size terhadap Profitabilitas melalui Capital Adequacy Ratio pada bank yang terdaftar di BEI periode 2014-2018. Sampel yang digunakan dalam penelitia ini adalah Bank BUMN yang terdiri dari empat Bank dan BUSN Devisa yang terdiri dari 10 Bank. Analisis yang digunakan untuk mengetahui hubungan langsung dan tidak langsung Non Performing Loan, Loan to Deposit Ratio, Beban Operasional Pendapatan Operasional dan Bank Size terhadap Profitabilitas Melalui Capital Adequacy Ratio adalah menggunakan Path Analysis. Berdasarkan hasil penelitian secara parsial Non Performing Loan dan Bank Size tidak terdapat pengaruh secara langsung dan tidak langsung terhadap Profitabilitas. Sedangkan Loan to Deposit Ratio dan Beban Operasional Pendapatan Operasional terdapat pengaruh langsung dan tidak langsung terhadap profitabilitas. Secara simultan dapat dilihat bahwa hasil uji simultan untuk Model 1 diperoleh nilai $\mathrm{F}_{\text {hitung }}$ sebesar 229.734 dengan $p$-value sebesar $0.000(<0.05)$, dan untuk Model 2 del 2 diperoleh nilai $\mathrm{F}_{\text {hitung }}$ sebesar 11.655 dengan $p$-value sebesar $0.000(<0.05)$
\end{abstract}

Kata Kunci: Bank, Beban Operasional Pendapatan Operasional, Capital Adequacy Ratio, Loan to Deposit Ratio, Non Performing Loan, Profitabilitas

\begin{abstract}
The purpose of this study is to determine the direct and indirect effects of Non-Performing Loans, Loan to Deposit Ratio, Operational Expenses of Operational Income and Bank Size on the Profitability through Capital Adequacy Ratio on banks listed on the Indonesia Stock Exchange in the period of 2014-2018. The samples used in this research are BUMN Banks consisting of four Banks and Foreign Exchange BUSN consisting of 10 Banks. The analysis used to determine the direct and indirect relationship of Non-Performing Loans, Loan to Deposit Ratio, Operating Expenses of Operational Income and Bank Size to the Profitability through Capital Adequacy Ratio is Path Analysis. Based on the results of the research in partial analysis, Non-Performing Loans and Bank Size have no direct and indirect effect on the profitability. However, Loan to Deposit Ratio and Operational Expenses of Operational Income have a direct and indirect effect on the profitability. Simultaneously, it can be seen that the simultaneous test results for Model 1 obtained $F_{\text {count }}$ value of 229,734 with p-value of 0,000 (<0.05), and for the 2 del 2 Model obtained $F_{\text {count }}$ value of 11,655 with p-value of 0,000 $(<0.05)$.
\end{abstract}

Keywords: Bank Size, Operating Expenses of Operational Income, Capital Adequacy Ratio, Loan to Deposit Ratio, NonPerforming Loans, Profitability 


\section{PENDAHULUAN}

Bank merupakan lembaga keuangan yang mempunyai peranan penting dalam perekonomian suatu negara. Fungsi utama bank adalah sebagai penghimpun dan penyalur dana kepada masyarakat atau dapat dikatakan bank merupakan lembaga intermediasi yang menjembatani pihak yang kelebihan dana (surplus spending unit) yang kemudian disalurkan kepada pihak yang kekurangan dana (defisit spending unit). Dalam hal ini perbankan berperan sangat dominan dalam kontribusi pada pembangangunan nasional indonesia, segala bentuk usaha Bank terutama Bank BUMN dikendalikan oleh pemerintah karena menyangkut resiko yang besar terutama pada saat krisis, hal terserbut menyebabkan keterbatasan lingkup gerak Bank BUMN dalam menarik deposan, namun pada pembahasan ini juga memasukan BUSN Devisa sebagai kompetitor Bank BUMN yang tujuan utamanya sebagai jembatan investor asing yang akan berinvestasi di indonesia, maka itu kinerja asing dapat tercermin pada besarnya investasi dan kekuatan Bank Asing bersaing dengan Bank BUMN dan Bank Swasta di indonesia.

Profitabilitas bank yang tinggi selain dipengaruhi oleh Non Performing Loan (NPL) juga dapat dipengaruhi oleh Loan to Deposit Ratio (LDR).Loan to Deposit Ratio (LDR) adalah rasio keuangan perusahaan perbankan yang digunakan untuk mengukur likuiditas bank. Rasio ini menunjukkan komposisi jumlah kredit yang diberikan dibandingkan dengan jumlah dana masyarakat dan modal sendiri yang digunakan (Kasmir,2014). Semakin tinggi jumlah dana yang disalurkan ke masyarakat menandakan bahwa rasio LDR pada bank tersebut tinggi. Rasio LDR yang tinggi akan berpengaruh pada tingkat profitabilitas bank karena dengan tingginya penyaluran kredit maka tingkat pendapatan bunga atau Income akan bertambah. Hal ini menandakan bahwa semakin tinggi penyaluran kredit yang dilakukan bank maka akan meningkatkan profitabilitas bank.

Ukuran perusahaan (Size) berpengaruh bagi perusahaan dalam mendapatkan laba. Pada umumnya semakin besar ukuran perusahaan akan dapat lebih menguntungkan, karena ukuran bank yang lebih besar mempunyai tingkat efisiensi yang lebih tinggi. Pengaruh Non Performing Loan (NPL), Loan to Deposit Ratio (LDR), dan Biaya Operasional Pendapatan Operasional (BOPO) terhadap Profitabilitas dapat dimediasi oleh Capital Adequacy Ratio (CAR). Capital Adequacy Ratio (CAR) menurut Dendawijaya (2009) dan Reni et al. (2019) bahwa rasio yang memperlihatkan seberapa jauh seluruh aktiva bank yang mengandung risiko ikut di biayai dari dana modal sendiri bank disamping memperoleh dana-dana dari sumber-sumber di luar bank, seperti dana dari masyarakat, pinjaman, dan lain-lain.

CAR berfungsi menampung risiko kerugian yang kemungkinan dihadapi oleh bank.CAR dapat berpengaruh positif maupun negatif terhadap Profitabilitas. Pengaruh positif CAR terhadap Profitabilitas dapat terjadi karena semakin besar modal berarti bank tersebut dapat menjadi faktor penentu berjalannya kegiatan operasional bank dalam menghimpun dana dan menyalurkannya kembali ke masyarakat. Semakin banyak modal yang dapat dikumpulkan oleh bank melalui aktivitas perbankan seperti menghimpun dana, menyalurkan dana, dan aktivitas pelayanan jasa, maka bank tersebut mampu membiayai kegiatan operasional dan memberikan kontribusi yang cukupbesar bagi profitabilitas sehingga bank dapat berjalan dengan baik karenabankmemiliki modal yang cukup untuk memenuhi kebutuhan bank maupun kebutuhan nasabah sehingga profitabilitas bank dapat meningkat.Rasio modal harus diperhatikan karena sebagian masyarakat melihat kesehatan bank melalui aspek permodalannya (Choerudin, 2016).Hal ini sejalan dengan kegiatan usaha perbankan yang mengandalkan kepercayaan masyarakat.

\section{METODE}

Populasi dalam penelitian ini adalah Bank BUMN dan BUSN Devisa pada periode tahun 2014-2018. Berdasarkan kriteria tertentu ditetapkan 14 bank sebagai sampel penelitian, yang terdiri dari 4 Bank BUMN dan 10 BUSN Devisa, sehingga total sampel selama periode penelitian adalah 14. Analisis yang digunakan untuk mengetahui hubungan langsung dan tidak langsung antara variabel bebas dan variabel terikat melalui variabel antara adalah mengukur Path Analysis. Kemudian menggunakan analisis regresi berganda untuk mengetahui variabel apa saja yang mempengaruhi profitabilitas.

\section{HASIL DAN PEMBAHASAN}

Kepercayaan masyarakat dapat timbul apabila bank memiliki modal yang kuat sehingga masyarakat tidak takut menyimpan dana mereka di bank karena bank diharapkan dapat memanfaatkan modal yang dimiliki untuk meningkatkan profitabilitasnya. Bank memerlukan modal yang cukup besar untuk menjalankan kegiatan operasional dan untuk menghadapi risiko kerugian yang akan timbul di kemudian hari. Jika bank memiliki nilai CAR yang tinggi, berarti bank tersebut memiliki cadangan modal yang tinggi pula. Namun bank yang memiliki CAR terlalu tinggi dapat mengakibatkan terjadinya idle fund, yaitu terdapat banyaknya dana yang menganggur yang tidak dapat dimanfaatkan oleh manajemen bank tersebut (Septiani, 2015). Modal yang dimiliki bank disalurkan kepada masyarakat dalam bentuk kredit yang dapat menghasilkan keuntungan berupa bunga yang akan digunakan bank untuk membayar segala jenis biaya-biaya operasional dan untuk berinvestasi dalam bentuk ekspansi perusahaan (Ismail, 2011). Bank yang memiliki nilai CAR yang rendah, akan kesulitan untuk melakukan ekspansi kredit kepada masyarakat dan mengakibatkan pendapatan yang diperoleh menurun. Selain itu, bank akan kesulitan ketika terjadi risiko kerugian akibat penyaluran kredit tersebut. 
Tabel 1 Kinerja Keuangan Bank Periode 2014-2018

\begin{tabular}{lccccc}
\hline Rasio (\%) & 2014 & 2015 & 2016 & 2017 & 2018 \\
\hline ROA & $1,94 \%$ & $1,67 \%$ & $2,32 \%$ & $2,23 \%$ & $2,45 \%$ \\
CAR & $16,49 \%$ & $18,39 \%$ & $21,39 \%$ & $22,93 \%$ & $23,18 \%$ \\
NPL & $2,12 \%$ & $2,59 \%$ & $1,96 \%$ & $2,54 \%$ & $1,92 \%$ \\
LDR & $85,64 \%$ & $85,98 \%$ & $89,42 \%$ & $92,11 \%$ & $90,04 \%$ \\
BOPO & $83,39 \%$ & $85,72 \%$ & $81,49 \%$ & $82 \%$ & $78,64 \%$ \\
Bank Size & $31,29 \%$ & $31,45 \%$ & $31,59 \%$ & $31,75 \%$ & $31,84 \%$ \\
\hline
\end{tabular}

Sumber: BPS 2020

Profitabilitas merupakan dasar dari adanya keterkaitan antara efisiensi operasional dengan kualitas jasa yang dihasilkan oleh suatu bank.Tujuan analisis profitabilitas sebuah bank adalah untuk mengukur tingkat efisiensi usaha yang dicapai oleh bank yang bersangkutan (Kuncoro, 2002). Menurut Weygandt et al. (2008), rasio profitabilitas adalah rasio yang digunakan untuk mengukur efektivitas manajemen perusahaan secara keseluruhan, yang ditunjukkan dengan besarnya laba yang diperoleh perusahaan. Return On Assets (ROA) merupakan salah satu rasio profitabilitas. Kuncoro (2002) menyatakan bahwa ROA menunjukkan kemampuan manajemen bank dalam mengelola aktiva yang tersedia untuk mendapatkan net income. Sedangkan Siamat (2005) mengemukakan bahwa ROA merupakan rasio yang memberikan informasi seberapa efisien suatu bank dalam melakukan kegiatan usahanya, karena rasio ini mengindikasikan seberapa besar keuntungan yang dapat diperoleh rata- rata terhadap setiap rupiah asetnya. Semakin besar ROA menunjukkan kinerja perusahaan semakin baik, karena return semakin besar.

Capital Adequacy Ratio (CAR) merupakan alat analisis yang digunakan untuk mengetahui berapa jumlah modal yang memadai untuk menunjang kegiatan operasionalnya dan cadangan untuk menyerap kerugian yang mungkin terjadi (Kuncoro,2002). Menurut Peraturan Bank Indonesia No. 9/13/PBI/2007, CAR adalah penyediaan modal minimum bagi bank didasarkan pada risiko aktiva dalam arti luas, baik aktiva yang tercantum dalam neraca maupun aktiva yang bersifat administrative sebagaimana tercermin pada kewajiban yang masih bersifat kontijen dan/atau komitmen yang disediakan oleh bank bagi pihak ketiga maupun risiko pasar.

Bank Indonesia menetapkan CAR sebagai rasio kecukupanmodal, merupakan rasio yang menunjukkan kewajiban penyediaan modal minimum yang harus dipertahankan oleh setiap bank sebagai proporsi tertentu dari total aktiva tertimbang menurut risiko. Ketentuan dariBank Indonesia menyatakan penyediaan CAR minimal $8 \%$. Jika rasio kecukupan modal ini semakin besar, maka tingkat keuntungan bank juga akan meningkat (Kuncoro,2002). Semakin tinggi nilai CAR (diatas 8\%) maka semakin baik pula kinerja keuangan bank, namun jika nilai CAR rendah (dibawah 8\%) maka kinerja keuangan bank buruk. CAR adalah rasio kinerja bank untuk mengukur kecukupan modal yang dimiliki bank untuk menunjang aktiva yang mengandung atau menghasilkan risiko, seperti kredit yang diberikan pada nasabah.
Bank akan dihadapkan pada risiko kredit yang tidak mampu dibayar oleh debitur sehingga menimbulkan kredit bermasalah dalam melakukan kegiatan pemberian kredit kepada nasabah. Menurut Rivai (2007) bahwa risiko kredit didefinisikan sebagai risiko yang terjadi akibat kegagalan pihak lawan dalam memenuhi kewajibannya.Menurut Siamat (2005) risiko kredit merupakan suatu risiko akibat kegagalan atau ketidak mampuan nasabah mengembalikan jumlah yang diterima dari bank beserta bunganya sesuai dengan jangka waktu yang telah ditetapkan atau dijadwalkan.Kredit bermasalah atau kredit macet adalah kredit yang didalamnya terdapat hambatan yang disebabkan oleh 2 unsur yakni dari pihak perbankan dalammenganalisis maupun dari pihak nasabah yang dengan sengaja atau tidak sengaja dalam kewajibannya tidak melakukan pembayaran (Kasmir,2014). NPL mencerminkan risiko kredit, semakin kecil NPL semakin kecil pula risiko kredit yang ditanggung pihak bank. Bank Indonesia menetapkan kriteria rasio NPL di bawah 5\%.

Siamat (2005), Non Performing Loan (NPL) atau sering disebut kredit bermasalah dapat diartikan sebagai pinjaman yang mengalami kesulitan pelunasan akibat adanya faktor kesengajaan atau karena faktor eksternal di luar kemampuan kendali debitur. Rasio ini menunjukkan kemampuan manajemen bank dalam mengelola kredit bermasalah yang diberikan oleh bank. Artinya, semakin tinggi rasio ini maka profitabilitas akan semakin buruk. Apabila kualitas kredit bank yang menyebabkan jumlah kredit bermasalah semakin besar, maka kemungkinan suatu bank dalam kondisi bermasalah semakin besar. Kerugian yang diakibatkan oleh kualitas kredit bermasalah dapat dilihat berdasarkan tingkat kolektibilitasnya, antara lain kredit lancar, dalam perhatian khusus (special mention), kurang lancar (substandard), diragukan (doubtful), dan macet (loss) (Peraturan Bank Indonesia No. 7/2/PBI/2005).

Pengelolaan likuiditas merupakan salah satu masalah yang dalam kegiatan operasional bank, hal tersebut dikarenakan dana yang dikelola bank sebagian besar adalah dana dari masyarakat yang bersifat jangka pendek dan dapat ditarik sewaktu-waktu. Likuiditas suatu bank berarti bahwa bank tersebut memiliki sumber dana yang cukup tersedia untuk memenuhi semua kewajiban (Siamat, 2005). Rasio likuiditas yang digunakan dalam perbankan diukur dari Loan to Deposit Ratio (LDR).

LDR (Loan to Deposit Ratio) merupakan rasio yang digunakan untuk mengukur komposisi jumlah kredit yang diberikan dibandingkan dengan jumlah dana masyarakat dan modal sendiri yang digunakan (Kasmir 2014). Menurut Dendawijaya (2009) Loan to Deposit Ratio (LDR) menyatakan seberapa jauh kemampuan bank dalam membayar kembali penarikan dana yang dilakukan nasabah dengan mengandalkan kredit yang diberikan sebagai sumber likuiditasnya. LDR merupakan rasio untuk mengukur kemampuan bank dalam membayar kembali kewajiban kepada para nasabah yang telah menanamkan dana dengan kredit yang telah diberikan 
kepada para debiturnya. Kredit yangdiberikan akan menjadi pendapatan berupa bunga, sehingga kredit dapat mengimbangi kewajiban bank untuk segera memenuhi permintaan nasabah yang ingin menarik kembali uang yang telah digunakan oleh bank untuk memberikan kredit melalui pendapatan bunga tersebut. Rasio ini juga merupakan indicator kerawanan dan kemampuan dari suatu bank. Peraturan Bank Indonesia No.18/14/PBI/2016 menyatakan bahwa batas aman dari LDR suatu bank adalah sekitar $80 \%$, namun batas toleransi berkisar antara $80 \%$ sampai $92 \%$. Batas maksimum rasio ini ditetapkan oleh Bank Indonesia.Batas maksimum LDR menurut peraturan pemerintah adalah sebesar92\%. Kredit disalurkan dengan efektif oleh bank akan meningkatkan pendapatan. Pendapatan bank yang tinggi dapat meningkatkan laba.Meningkatnya laba bank menyebabkan Profitabilitas juga meningkat. Dengan demikian maka LDR berpengaruh positif terhadap Profitabilitas.

Salah satu indikator yang digunakan untuk mengukur efisiensi bank adalah perbandingan antara biaya operasional pendapatan operasional (BOPO).Rasio ini mencerminkan tingkat efisiensi bank dalam menjalankan operasionalnya. Menurut Rivai, et.al (2013), BOPO adalah rasioyang digunakan untuk mengukur tingkat efisiensi dankemampuan bank dalam melakukan kegiatan operasinya. Menurut Hasibuan (2008), BOPO merupakan perbandingan atau rasio biaya operasional dalam 12 bulan terakhir terhadap pendapatan operasional dalam periode yang sama. BOPO adalah rasio perbandingan antara biaya operasional dengan pendapatan operasional.Semakin rendah tingkat rasio BOPO berarti semakin baik kinerja manajemen bank tersebut. Besarnya BOPO yang dapat ditolerir oleh perbankan Indonesia adalah sebesar 93,5\% (Kuncoro,2011).

BOPO merupakan rasio antara biaya yang dikeluarkan oleh bank dalam menjalankan aktivitas utamanya terhadap pendapatan yang diperoleh dari aktivitas tersebut. Aktivitas utama bank seperti biaya bunga, biaya tenaga kerja, biaya pemasaran dan biaya operasi lainnya, sedangkan pendapatan operasional adalah pendapatan bunga yang diperoleh dari penempatan dana dalam bentuk kredit dan pendapatan operasi lainnya. Semakin kecil rasio BOPO menunjukkan semakin efisien suatu bank dalam menjalankan aktivitas usahanya karena biaya yang dikeluarkan bank semakin kecil sehingga profitabilitas bank tetap terjaga. Bank Indonesia menetapkan angka terbaik untuk rasio BOPO adalah dibawah 90\%, karena jika rasio BOPO melebihi $90 \%$ hinggamendekati angka $100 \%$, bank tersebut dapat dikategorikan tidak efisien dalam menjalankan operasinya.

Bank Size atau ukuran perusahaan pada dasarnya merupakan hal yang penting dalam suatu perusahaan. Hal tersebut dikarenakan ukuran perusahaan menggambarkan besar keciya suatu perusahaan dapat ditunjukkan oleh total aset, jumlah penjualan, rata-rata tingkat penjualan dan rata-rata total aset (Ferri and Jones dalam Tri kumala, 2012). Sedangkan bank size merupakan besarnya total assets yang dimiliki perusahaan. Pada neraca bank, asset menunjukkan posisi penggunaan dana (Kuncoro dan Suhardjono, 2002).

Manajemen bank dengan jumlah aset yang lebih tinggi cenderung berupaya untuk meningkatkan jumlah kecukupan modalnya (Mekonnen, 2015). Jogiyanto (2007) menyatakan bahwa Ukuran aktiva digunakan untuk mengukur besarnya perusahaan, ukuran aktiva tersebut diukur sebagai logaritma dari total aktiva. Teori trade-off menyatakan bahwa apabila ukuran perusahaan meningkat, akan lebih mudah untuk mengakses pasar modal dengan biaya transaksi yang lebih rendah. Semakin besar ukuran perusahaan menyebabkan biaya produk yang dihasilkan perusahaan akan semakin rendah (Pratama, 2013). Ukuran suatu bank dapat diproksikan dengan keseluruhan aktiva yang dimilikinya. Apabila aktiva perusahaan yang merupakan sumber daya bagi perusahaan dimanfaatkan dengan baik maka tentu akan meningkatkan penghasilan (Putri, 2015). Ukuran bank diketahui berpengaruh signifikan terhadap CAR.

Penelitian menunjukkan gambaran variable penelitian berupa.

Tabel 2 Variabel Penelitian

\begin{tabular}{lcccccc}
\hline Statistik & Profitabilitas & CAR & NPL & LDR & BOPO & $\begin{array}{c}\text { Bank } \\
\text { Size }\end{array}$ \\
\hline Minimum & $-4.9 \%$ & $10.4 \%$ & $0.0 \%$ & $51.6 \%$ & $58.2 \%$ & 8.66 \\
Maksimum & $4.8 \%$ & $48.4 \%$ & $6.4 \%$ & $108.9 \%$ & $150.8 \%$ & 14.08 \\
Rata-rata & $1.8 \%$ & $18.9 \%$ & $1.5 \%$ & $85.3 \%$ & $82.8 \%$ & 12.00 \\
Standar & $1.4 \%$ & $5.1 \%$ & $1.1 \%$ & $12.0 \%$ & $13.5 \%$ & 1.30 \\
Deviasi & & & & & & \\
\hline Sumber: Analisi Data, 2020 & & & & &
\end{tabular}

Berdasarkan Tabel 2. terlihat bahwa profitabilitas berada diantara $-4.9 \%$ sampai $4.8 \%$ dengan rata-rata sebesar $1.8 \%$ dan standar deviasi sebesar 1.4\%; CAR berada diantara $10.4 \%$ dan $48.4 \%$ dengan rata-rata sebesar $18.9 \%$ dan standar deviasi sebesar $5.1 \%$; NPL berada diantara $0.0 \%$ sampai $6.4 \%$ dengan rata-rata sebesar $1.5 \%$ dan standar deviasi sebesar $1.1 \%$; LDR berada diantara $51.6 \%$ da $108.9 \%$ dengan rata-rata sebesar $85.3 \%$ dan standar deviasi sebesar $12.0 \%$; BOPO berada diantara $58.2 \%$ sampai $150.8 \%$ dengan rata-rata sebesar $82.8 \%$ dan standar devisi sebesar $13.5 \%$; sedangkan Bank Size berada diantara 8.66 sampai 14.08 dengan rata-rata sebesar 12.00 dan standar deviasi sebesar 1.30 .

Hasil uji simultan (Tabel 3) untuk Model 1 diperoleh nilai $F_{\text {hitung }}$ sebesar 229.734 dengan $p$-value sebesar 0.000 ( $<0.05)$ sehingga $\mathrm{H}_{0}$ ditolak. Dengan demikian dapat disimpulkan bahwa terdapat pengaruh yang signifikan dari variabel NPL, LDR, BOPO, Bank Size, dan CAR terhadap variabel Profitabilitas secara simultan. Tabel 3 juga menunjukkan bahwa untuk Model 2 diperoleh nilai $\mathrm{F}_{\text {hitung }}$ sebesar 11.655 dengan p-value sebesar 0.000 (< 0.05) sehingga $\mathrm{H}_{0}$ ditolak. Dengan demikian dapat disimpulkan bahwa terdapat pengaruh yang signifikan dari variabel NPL, LDR, BOPO dan Bank Size terhadap variabel CAR secara simultan. 
Tabel 3 Uji Hipotesis Uji Simultan (Uji F)

\begin{tabular}{lcc}
\hline \multicolumn{1}{c}{ Model } & $\mathrm{F}_{\text {hitung }}$ & p-value \\
\hline $\begin{array}{l}\text { NPL, LDR, BOPO, Bank Size, dan } \\
\text { CAR terhadap Profitabilitas }\end{array}$ & 229.734 & 0.000 \\
$\begin{array}{l}\text { NPL, LDR, BOPO dan Bank Size } \\
\text { terhadap CAR }\end{array}$ & 11.655 & 0.000 \\
\hline Sumber: Analisi Data, 2020 & &
\end{tabular}

Sumber: Analisi Data, 2020

Tabel 4 dapat dilihat bahwa hasil uji t diperoleh nilai $t_{\text {hitung }}$ sebesar 1.015dengan p-value sebesar $0.314(>0.05)$ sehingga $\mathrm{H}_{0}$ diterima. Dengan demikian dapat disimpulkan bahwa tidak terdapat pengaruh dari NPL secara langsung terhadap Profitabilitas

Tabel 4 Uji Parsial Pengaruh NPL secara Langsung Terhadap Profitabilitas

\begin{tabular}{lccc}
\hline \multicolumn{1}{c}{ Variabel } & $\begin{array}{c}\text { Besar } \\
\text { Pengaruh }\end{array}$ & $\mathrm{t}_{\text {hitung }}$ & p-value \\
\hline $\begin{array}{l}\text { NPL terhadap } \\
\text { Profitabilitas }\end{array}$ & $0.138 \%$ & 1.015 & 0.314 \\
\hline Sumber: Analisi Data, 2020 & & & \\
\hline
\end{tabular}

Tabel 5 Uji Parsial Pengaruh NPL secara Langsung Terhadap Profitabilitas melalui CAR

\begin{tabular}{lccc}
\hline \multicolumn{1}{c}{ Variabel } & $\begin{array}{c}\text { Besar } \\
\text { Pengaruh }\end{array}$ & t $_{\text {hitung }}$ & p-value \\
\hline NPL terhadap & $0.053 \%$ & 0.038 & 0.970 \\
Profitabilitas melalui & & & \\
CAR & & & \\
\hline Sumber: Analisi Data, 2020 & & &
\end{tabular}

Berdasarkan Tabel 5 dapat dilihat bahwa hasil uji sobel diperoleh nilai Zhitung sebesar 0.038 dengan pvalue sebesar 0.970 (> 0.05 ) sehingga H0 diterima. Dengan demikian dapat disimpulkan bahwa tidak terdapat pengaruh dari NPL secara tidak langsung terhadapProfitabilitas melalui CAR.

Tabel 6 Uji Parsial LDR secara Langsung Terhadap Pofitabilitas

\begin{tabular}{|c|c|c|c|}
\hline Variabel & $\begin{array}{c}\text { Besar } \\
\text { Pengaruh }\end{array}$ & $t_{\text {hitung }}$ & p-value \\
\hline $\begin{array}{l}\text { LDR terhadap } \\
\text { Profitabilitas }\end{array}$ & $0.523 \%$ & -1.969 & 0.053 \\
\hline \multicolumn{4}{|l|}{ Sumber: Analisi Data, 2020} \\
\hline \multicolumn{4}{|c|}{$\begin{array}{l}\text { Berdasarkan Tabel } 6 \text { dapat dilihat bahwa hasil uji } \mathrm{t} \\
\text { diperoleh nilai } \mathrm{t}_{\text {hitung }} \text { sebesar }-1.969 \text { dengan } p \text {-value } \\
\text { sebesar } 0.053(>0.05) \text { sehingga } \mathrm{H}_{0} \text { diterima. Dengan } \\
\text { demikian dapat disimpulkan bahwa tidak terdapat } \\
\text { pengaruh dari LDR secara langsung terhadap Profitabilitas }\end{array}$} \\
\hline \multicolumn{4}{|c|}{$\begin{array}{c}\text { Tabel } 7 \text { Uji Parsial LDR secara Tidak Langsung } \\
\text { Terhadap Profitabilitas Melaui CAR }\end{array}$} \\
\hline Variabel & $\begin{array}{c}\text { Besar } \\
\text { Pengaruh }\end{array}$ & $t_{\text {hitung }}$ & $\mathrm{p}$-value \\
\hline $\begin{array}{l}\text { LDR terhadap } \\
\text { Profitabilitas melalui } \\
\text { CAR }\end{array}$ & $0.049 \%$ & 0.038 & 0.970 \\
\hline
\end{tabular}

Berdasarkan Tabel 7 dapat dilihat bahwa hasil uji sobel diperoleh nilai Zhitung sebesar 0.038 dengan pvalue sebesar 0.970 (> 0.05) sehingga H0 diterima. Dengan demikian dapat disimpulkan bahwa tidak terdapat pengaruh dari LDR secara tidak langsung terhadapProfitabilitas melalui CAR.

Tabel 8 Uji Parsial Pengaruh BOPO terhadap Profitabilitas Secara Langsung

\begin{tabular}{lccc}
\hline \multicolumn{1}{c}{ Variabel } & $\begin{array}{c}\text { Besar } \\
\text { Pengaruh }\end{array}$ & $\mathrm{t}_{\text {hitung }}$ & $\mathrm{p}$-value \\
\hline $\begin{array}{l}\text { BOPO terhadap } \\
\text { Profitabilitas }\end{array}$ & $90.234 \%$ & -23.925 & 0.000 \\
\hline Sumber: Analisi Data, 2020 & & &
\end{tabular}

Sumber: Analisi Data, 2020

Berdasarkan Tabel 8 dapat dilihat bahwa hasil uji t diperoleh nilai thitung sebesar -23.925 dengan p-value sebesar $0.000(<0.05)$ sehingga H0 ditolak. Dengan demikian dapat disimpulkan bahwa terdapat pengaruh dari BOPO secara langsung terhadap Profitabilitas. Besar pengaruh langsung dari $\mathrm{BOPO}$ terhadap Profitabilitas merupakan kuadrat dari koefisien jalur BOPO terhadap Profitabilitas, yaitu $(-0.950) 2=0.90234=90.234 \%$.

Tabel 9 Uji Parsial Pengaruh BOPO Seacara Tidang Langsung Terhadap Profitabilitas Melalui CAR

\begin{tabular}{llll}
\multicolumn{1}{c}{ Variabel } & $\begin{array}{c}\text { Besar } \\
\text { Pengaruh }\end{array}$ & $\mathrm{t}_{\text {hitung }}$ & $\mathrm{p}$-value \\
\hline $\begin{array}{l}\text { BOPO terhadap } \\
\text { Profitabilitas melalui } \\
\text { CAR }\end{array}$ & $0.015 \%$ & 0.038 & 0.970 \\
\hline Sumber: Analisi Data, 2020 & & & \\
\hline
\end{tabular}

Berdasarkan Tabel 9 dapat dilihat bahwa hasil uji sobel diperoleh nilai $Z_{\text {hitung }}$ sebesar 0.038 dengan $p$-value sebesar 0.970 (> 0.05) sehingga $\mathrm{H}_{0}$ diterima. Dengan demikian dapat disimpulkan bahwa tidak terdapat pengaruh dari BOPO secara tidak langsung terhadap Profitabilitas melalui CAR.

Tabel 10 Uji Parsial Pengaruh Bank Size secara langsung terhadap Profitabilitas

\begin{tabular}{llll}
\hline \multicolumn{1}{c}{ Variabel } & $\begin{array}{c}\text { Besar } \\
\text { Pengaruh }\end{array}$ & $\mathrm{t}_{\text {hitung }}$ & $\mathrm{p}$-value \\
\hline $\begin{array}{l}\text { Bank Sizeterhadap } \\
\text { Profitabilitas }\end{array}$ & $0.532 \%$ & 1.772 & 0.081 \\
\hline Sumber: Analisi Data, 2020 & & &
\end{tabular}

Berdasarkan Tabel 10 dapat dilihat bahwa hasil uji $\mathrm{t}$ diperoleh nilai thitung sebesar 1.772dengan p-value sebesar 0.081 (> 0.05) sehingga H0 diterima. Dengan demikian dapat disimpulkan bahwa tidak terdapat pengaruh dari Bank Sizesecaralangsung terhadap Profitabilitas/

Tabel 11 Uji parsial Bank Size secara Tidak Langsung

\begin{tabular}{lccc}
\hline \multicolumn{1}{c}{ Variabel } & $\begin{array}{c}\text { Besar } \\
\text { Pengaruh }\end{array}$ & $\mathrm{t}_{\text {hitung }}$ & p-value \\
\hline $\begin{array}{l}\text { Bank Size terhadap } \\
\text { Profitabilitas melalui CAR }\end{array}$ & $0.023 \%$ & 0.038 & 0.970 \\
\hline Sumber: Analisi Data, 2020 & & &
\end{tabular}

Berdasarkan Tabel 11 dapat dilihat bahwa hasil uji sobel diperoleh nilai Zhitung sebesar 0.038 dengan p- 
value sebesar 0.970 (> 0.05 ) sehingga H0 diterima. Dengan demikian dapat disimpulkan bahwa tidak terdapat pengaruh dari Bank Sizesecara tidak langsung terhadap Profitabilitas melalui CAR

Tabel 12 Pengaruh CAR secara Langsung terhadap Profitabilitas

\begin{tabular}{lccl}
\hline \multicolumn{1}{c}{ Variabel } & $\begin{array}{c}\text { Besar } \\
\text { Pengaruh }\end{array}$ & $\mathrm{t}_{\text {hitung }}$ & $\mathrm{p}$-value \\
\hline $\begin{array}{l}\text { CAR terhadap } \\
\text { Profitabilitas }\end{array}$ & $0.0002 \%$ & -0.038 & 0.970 \\
\hline
\end{tabular}

Sumber: Analisi Data, 2020

Berdasarkan Tabel 12 dapat dilihat bahwa hasil uji t diperoleh nilai thitung sebesar -0.038 dengan p-value sebesar 0.970 (> 0.05) sehingga H0 diterima. Dengan demikian dapat disimpulkan bahwa tidak terdapat pengaruh dari CAR secara langsung terhadap Profitabilitas.

Tabel 13 Koefisien Determinasi

\begin{tabular}{llll}
\hline \multicolumn{1}{c}{ Variabel } & $\begin{array}{c}\text { Besar } \\
\text { Pengaruh }\end{array}$ & $\mathrm{t}_{\text {hitung }}$ & p-value \\
\hline $\begin{array}{l}\text { Bank Sizeterhadap } \\
\text { Profitabilitas }\end{array}$ & $0.532 \%$ & 1.772 & 0.081 \\
\hline Sumber: Analisi Data, 2020 & & &
\end{tabular}

Sumber: Analisi Data, 2020

Berdasarkan Tabel 13 dapat diketahui bahwa untuk model 1 hasil koefisien korelasi yang diperoleh adalah 0.971. Maka diperoleh data R2 adalah 0.943. Koefisien determinasi dihitung dengan cara mengkuadratkan hasil korelasi kemudian dikalikan dengan $100 \%$. Maka nilai koefisien determinasi diperoleh $0.943 \times 100 \%$, sebesar 94.3\%. Berarti kemampuan variabel bebas dalam menjelaskan varians dari variabel terikat pada model 1 adalah sebesar $94.3 \%$, sehingga terdapat $5.7 \%$ varians variabel terikat yang dijelaskan oleh faktor lain.

Sedangkan untuk model 2 diperoleh nilai koefisien korelasi sebesar 0.632, maka diperoleh R2 adalah 0.400. Sehingga koefisien determasi yang diperoleh adalah sebesar 40.0\%. Hal ini menunjukkan bahwa kemampuan variabel bebas dalam menjelaskan varians dari variabel terikat pada model 2 adalah sebesar $40.0 \%$, sehingga terdapat $60.0 \%$ varians variabel terikat yang dijelaskan oleh faktor lain

\section{SIMPULAN}

Hasil penelitian menunjukkan bahwa tidak terdapat pengaruh dari LDR secara langsung terhadap Profitabilitas. Sedangkan terdapat pengaruh dari BOPO secara langsung terhadap Profitabilitas. Besar pengaruh langsung dari BOPO terhadap Profitabilitas merupakan kuadrat dari koefisien jalur BOPO terhadap Profitabilitas. Sedangka $\mathrm{n}$ tidak terdapat pengaruh dari Bank Size secaralangsung terhadap Profitabilitas.

\section{DAFTAR PUSTAKA}

Ahmad, Rubi., M. Ariff., Skully, Michael J. 2008. The Determinants of Bank Capital Ratios in a
Developing Economy. Asia-Pacific Finan Markets(1): 255-272.

Aktas, Rafet. Acikalin, Suleyman. Bakin, Bilge. Celik, Gokhan. 2015. The Determinants of Banks' Capital Adequacy Ratio : Some Evidence from South Eastern European Countries. Journal Economics and Behavioral Studies, 7 (1), 79-88.

Al-Sabbagh, Noor Mohammad. 2004. Determinants of Capital Adequacy Ratio in Jordanian Banks, Thesis, The Degree of Master of (Banking \& Finance Sciences) at Yarmouk University.

Choerudin, Ahmad, EnyYuniatun, dan BambangKusdiasmo. (2016). Pengaruh Non Perfoming Loan (NPL) dan Loan to Deposit Ratio (LDR) terhadap Return on Asset (ROA) dengan Capital Adequacy Ratio (CAR) sebagai Variabel Intervening (Studi Pada Bank Umum Yang Terdaftar Di BEIPeriodeTahun20122015).ProBank,JurnalEkonomidanPerbankan.Vol2. No. 2.h:28-47.

Dendawijaya, Lukman. (2009). Manajemen Perbankan. Jakarta: Ghalia Indonesia. Ghozali, Imam. (2012). Aplikasi Analisis Multivariate Dengan Program IBM SPSS20 Cetakan VI. Semarang: Badan Penerbit Universitas Diponegoro.

Dreca, Nada. 2013. Determinants of Capital Adequacy Ratio in Selected Bosnian Banks. Dumlupinar Üniversitesi Sosyal Bilimler Dergisi EYI

Hasibuan, Malayu S. P. (2008). Dasar-Dasar Perbankan. Jakarta: Bumi Aksara.

Ismail. (2011). Manajemen Perbankan: dari Teori Menuju Aplikasi. Cetakan KeDua.Jakarta: Kencana Prenada Media Group.

Kasmir.(2014). Analisis Laporan Keuangan. Jakarta: PT.Raja Grafindo Persada.

Kuncoro, Mudrajad (2001). Metode Kuantitatif: Teori dan Aplikasi untuk Bisnis dan Ekonomi. Yogyakarta: UPP AMP YKPN.

Kuncoro, Mudrajad dan Suhardjono.(2002). Manajemen Perbankan Teori dan Aplikasi. Yogyakarta: Penerbit BPFE.

Kuncoro, Mudrajad. (2011). Survei Perkembangan Indikator Kerja. Jurnal Megadigma.

Reny, A. R., Saleh, M. Y., \& Sapiri, M. 2019. Pengaruh Return On Asset Dan Tobin's Q Terhadap Volume Perdagangan Saham Pada Perusahaan Perbankan Yang Listing Di Bursa Efek Indonesia Periode Tahun 2013-2017. Indonesian Journal of Business and Management, 1(2), 09-16.

Rivai, Veithzal, dan Andria Permata Veithzal. (2007). Credit Management Handbook: Teori, Konsep, Prosedur dan Aplikasi Panduan Praktis Mahasiswa, Bankir, dan Nasabah. Jakarta: PT. Raja Grafindo Persada.

Rivai, Veithzal, et al. (2013). Commercial Bank Management: Manajemen Perbankan dari Teori ke Praktik. Depok: PT. Raja Grafindo Persada.

Septiani,Rita.(2015).Pengaruh NPL dan LDR terhadap Profitabilitas dengan CAR sebagai Variabel Mediasi 
pada PT BPR Pasarraya Kuta.E-Jurnal ISSN: 23028912. Manajemen Unud. Vol. 5, No.1, h: 293 - 324.

Shaddady, Ali, and Moore, Tomoe. 2015. Determinants of Capital Adequacy Ratio in Oil Exporting Countries: Evidence from GCC Commercial Banks. Second Middle East Conference on Global Business, Economics, Finance and Banking (ME15Dubai Conference), 22-24 May, 2015

Siamat, Dahlan. (2005). Manajemen Lembaga Keuangan. Jakarta: Lembaga Penerbit Ekonomi Universitas Indonesia.

Weygandt, Jerry J., et. al. (2008).Accounting Principles. New Jersey: John Wiley \&Sons.Inc. 